\title{
Sobre a história da política externa da Rússia: o "paradigma” de Primakov
}

Alexander Zhebit ${ }^{*}$

${ }^{1}$ Universidade Federal do Rio de Janeiro, Rio de Janeiro, Brasil.

\section{RESUMO}

Baseada na leitura das obras publicadas do antigo chanceler e primeiro-ministro russo Evguêni Primakov, com destaque na sua atuação nos governos de Mikhail Gorbachev e Boris Yeltsin, o artigo debruça-se sobre alguns vetores fundamentais da política externa russa nas relaçóes internacionais, marcadas atualmente pela crise político-diplomática no relacionamento entre a Rússia e os Estados Unidos e seus aliados. A influência das ideias deste estadista sobre a diplomacia da Rússia no que tange à segurança internacional, ao papel da OTAN na Europa, à crise no Oriente Médio e à arquitetura da ordem mundial leva a pensar num "paradigma", que constitui, em seus traços gerais, um núcleo conceitual inerente à atual estratégia internacional, seguida pelos governos de Vladimir Putin.

Palavras-chave: história da política externa russa; Evguêni Primakov; expansão da OTAN; Oriente Médio; multipolaridade.

\section{On the history of Russian foreign policy: Primakov's "paradigm"}

\section{ABSTRACT}

Based on a reading of the published works by the former Russian Foreign and Prime Minister Evgeny Primakov, with a focus on his tenure in the governments of Mikhail Gorbachev and Boris Yeltsin, the article dwells upon some fundamental vectors of Russian foreign policy in international relations, marked actually by a political and diplomatic crisis in the relationship between Russia and the United States and its allies. The influence of this statesman's ideas on Russian diplomacy, in its aspects of international security, NATO's role in Europe, the crisis in the Middle East and the architecture of world order, suggests a

DOI: http://dx.doi.org/10.1590/2237-101X02004107

Artigo recebido em 24 de junho de 2018 e aceito para publicação em 20 de dezembro de 2018.

* Professor da Universidade Federal do Rio de Janeiro/Centro de Filosofia e Ciências Humanas/Núcleo de Estudos de Políticas Públicas em Direitos Humanos, Rio de Janeiro/RJ — Brasil. E-mail: alex@cfch.ufrj.br. ORCID: https://orcid.org/0000-0001-9321-2210. 
"paradigm". Such a paradigm, in its general features, shapes an inherent conceptual core of the current international strategy, followed by the governments of Vladimir Putin.

Keywords: history of Russian foreign policy; Yevgeni Primakov; NATO expansion; Middle East; multipolarity.

\section{Sobre la historia de la política externa de Rusia: el "paradigma" de Primakov}

\section{RESUMEN}

Basado en la lectura de las obras publicadas por el antiguo Canciller y Primer Ministro ruso Evguêni Primakov, con destaque en su actuación en los gobiernos de Mikhail Gorbachev y Boris Yeltsin, el artículo se enfoca en algunos vectores fundamentales de la política externa rusa en las relaciones internacionales, marcadas actualmente por la crisis político-diplomática en el relacionamiento entre Rusia, Estados Unidos y sus aliados. La influencia de las ideas de este estadista sobra la diplomacia en Rusia en lo que se refiere a seguridad internacional, al papel de la OTAN en Europa, a la crisis en el Medio Oriente e a la arquitectura del orden mundial, lleva a pensar en un "paradigma" que constituye en sus trazos generales un núcleo conceptual inherente a la actual estrategia internacional seguida por los gobiernos de Vladimir Putin.

Palabras clave: historia de la política externa rusa; Yevgeni Primakov; expansión de la OTAN; Oriente Medio; multiporalidad.

\section{Introdução}

A reflexão sobre o papel da Rússia nas relações internacionais atuais desemboca inevitavelmente na necessidade da análise de um passado recente da sua política externa, em que se denota o surgimento de uma persistente estratégia paradigmática para com o exterior, com suas condicionalidade, objetividade, intencionalidade e racionalidade. A personalidade, cujo protagonismo marcou a transformação da política externa da nova Rússia, desde meados dos anos 1990, foi Evguêni Primakov. ${ }^{1}$

\footnotetext{
${ }^{1}$ O estadista russo Evguêni Maksímovitch Primakov (1929-2015) foi um orientalista de formação, jornalista em países do Oriente Médio, doutor em economia política, membro efetivo da Academia de Ciências da União Soviética e da Rússia. Presidiu o Conselho da União do Soviete Supremo durante o governo de Gorbachev (1989-1990). Foi dirigente do Serviço Central de Inteligência soviético em 1991. Nos anos 1992-1995 dirigiu o Serviço de Inteligência Externa da Federação da Rússia (1992-1995). Foi ministro das Relaçóes Exteriores (1996-1998), primeiro-ministro do Governo da Federação da Rússia (1998-1999), deputado da
} 
Lembrado como alguém cujas capacidades de intelecto, dom diplomático e liderança foram reconhecidas pelos contemporâneos, Primakov tem sido referenciado como um dos fundadores da atual conceituação da política externa da Rússia pós-soviética, inclusive pelo presidente Vladimir Putin, que se associa com o ideário político-diplomático de Primakov² e cujo legado ele "aprimorou e consolidou".

A alteração da política externa russa em meados dos 1990, em comparação com o seu rumo externo no início da década, havia sido percebida por pesquisadores da área, táo logo Primakov assumiu a função de chanceler:

Primakov foi a figura-chave na orientação da política externa russa em direção ao rumo da busca de status independente de grande potência, mas no Ocidente seu papel foi ignorado ou mal compreendido [...] Ele rejeitou explicitamente a analogia de comparação da Rússia póscomunista com a Alemanha e o Japão pós-Segunda Guerra Mundial, países que barganharam a soberania nas relaçốes internacionais pela integração e pela prosperidade no âmbito da arquitetura ocidental de segurança. ${ }^{4}$

Para entender quão diferente foi a fase da diplomacia pós-soviética antes da nomeação de Primakov como chanceler, deve ser lembrado que a Rússia demonstrou uma notável fraqueza na etapa inicial de sua inserção na ordem internacional pós-Guerra Fria. Diminuída significativamente em termos territoriais, populacionais, econômicos e militares, em comparação com a União Soviética, o país teve que se deparar tanto com conflitos civis e interétnicos no antigo espaço soviético como segurar tendências separatistas dentro do próprio país, que evoluía pela "trajetória descendente da condição de superpotência mundial ao nível de uma frouxa confederação com fraca presença na Eurásia”.

Sob a influência inercial da doutrina externa de Mikhail Gorbachev, a predominância de interesses "de toda a humanidade" seria concretizada mediante a adesão obrigatória às instituiçôes internacionais neoliberais, demonstrando uma solidariedade inequívoca com o Ocidente. Tendo se submetido à pressão acérrima de empréstimos financeiros, na expec-

Duma (2000-2001), presidente da Câmara de Comércio e Indústria da Rússia (2001-2011).

2 PRIMAKOVSKIE TCHTÊNIA. Fórum internacional. 30 de novembro de 2016. Disponível em: http:// kremlin.ru/events/president/news/53361 Acesso em: 15 novembro 2017.

${ }^{3}$ MANKOFF, Jeffrey. Russia and the West: Taking the Longer View. The Washington Quarterly, v. 30, n. 2, p. 124, Spring 2007.

${ }^{4}$ Primakov was a key figure in setting Russian foreign policy on its course of seeking independent greatpower status, but in the West his role has often been overlooked or misunderstood. [...] He explicitly rejected the analogy comparing post-Communist Russia to post-World War II Germany and Japan, countries that traded international sovereignty for integration as well as prosperity inside the Western security architecture (MANKOFF, Jeffrey. Russia and the West: Taking the Longer View, op. cit., p. 125). (Tradução do autor.) ${ }^{5}$ JÉBIT, Alexandre A. Reflexóes sobre a nova concepção da política externa da Rússia. Contexto Internacional, v. 15, n. 2, jul./dez. 1993, p. 260. 
tativa de que "o Ocidente nos ajudará", 6 a Rússia vinha sendo arrastada para a situação de dependência econômica e financeira do mundo desenvolvido.

O conhecido fato de Andrei Kozyrev, primeiro chanceler dos governos de Yeltsin, ter solicitado ao ex-presidente dos Estados Unidos Richard Nixon, em visita a Moscou em 1994, que o ajudasse a formular interesses nacionais da Rússia, ${ }^{7}$ dizia muita coisa sobre o estado da desorientação e da fragilidade do poder estatal, mas, sobretudo, sobre a inclinação da nova liderança da Rússia a se adequar à ordem mundial unipolar, liderada pela superpotência remanescente.

O primeiro conceito da política externa da Rússia foi elaborado no meio de um acirrado conflito entre os ramos de poderes executivo e legislativo. Uma ênfase dada naquele documento às relaçóes com o "exterior próximo" pós-soviético, ou seja, com a Comunidade dos Estados Independentes (CEI), não foi equilibrada pelo objetivo da manutenção da segurança da Rússia, com relação à OTAN e aos Estados Unidos. A “estreita interação" com o bloco ocidental e a prioridade atribuída às relaçôes com os Estados Unidos, numa crença nos "interesses nacionais básicos [dos Estados Unidos], livres da sujeição à conjuntura política interna”, ${ }^{8}$ expressaram não exatamente uma ingenuidade ou ambiguidade doutrinárias, mas, sobretudo, uma coerência pró-ocidental dos objetivos da política externa do governo de Yeltsin.

$\mathrm{O}$ advento de Primakov na política, nos últimos anos da União Soviética ${ }^{9}$ e nos primeiros da Rússia, como chefe da inteligência, depois, como ministro das Relaçôes Exteriores e, em seguida, primeiro-ministro, foi fundamental para a definição de interesses do Estado da Rússia e para a construção da sua doutrina externa. No período de incertezas políticas e de desorientação, quando a política externa foi o pomo de discórdia entre a Duma, o Conselho de Segurança, os Ministérios da Defesa e das Relaçôes Exteriores, Primakov, ao assumir a pasta, criticou a postura pró-ocidental de Kozyrev, centralizou a condução da diplomacia no Ministério das Relações Exteriores, sob a autoridade de Yeltsin, ${ }^{10}$ e andou em direção à correção substancial do rumo político exterior. ${ }^{11}$

\footnotetext{
6 Запад нам поможет. (Referência à frase proverbial, atribuída a Ostap Bender, protagonista dos romances soviéticos satíricos (ILF, Iliá Arnóldovich; PETROV, Evguêni Petróvich. Dvenadtsat'stúliev. Zolotói teliônok. Kívv: Radziánski písmennik, 1957. p. 121). (Tradução do autor.)

${ }^{7}$ SIMES, Dimitri K. After the Collapse: Russia Seeks its Place as a Great Power. Nova York: Simon \& Schuster, 1999. p. 203-204.

${ }^{8}$ Foreign Policy and National Security of contemporary Russia. 1992-2002. Anthology in four volumes. Vol. IV. Documents. Moscou: Moscow State Institute of International Relations (University), Russian International Studies Association, ISE-Center (Information. Scholarship. Education.), 2002. p. 29, 31, 38.

${ }^{9}$ Em agosto de 1991, Primakov, na qualidade do presidente do Conselho da União do Soviete Supremo da URSS, foi a Foros na Crimeia, integrando a comissão dirigida por Aleksandr Rutskoi, vice-presidente da Federação da Rússia, para resgatar Mikhail e Raíssa Gorbachev do sequestro por conspiradores do putsch comunista.

10 PRIMAKOV, E. M. Vstrêtchi na perekrióstkakh/Evguêni Primakov. Moscou: ZAO Izdatelstvo Tsentrpoligraf, 2015. p. 197.

${ }^{11}$ LARRABEE, F. Stephen; KARACIK, Theodore. Foreign and Security Policy Decisionmaking under Yeltsin. National Defense Research Institute. Washington, D.C.: RAND, 1997. p. 50.
} 
O novo chanceler formulou conceitos básicos da política externa russa na sua primeira coletiva em 12 de janeiro de 1996. Em alusão crítica ao seu antecessor, Primakov, ao ecoar Palmerston, assinalou que não há "adversários permanentes", mas há "interesses permanentes", que não devem ser sacrificados, quer em prol da "luta contra adversários permanentes", quer em defesa de "aliados permanentes". ${ }^{12}$ Contrariando os seguidores da rapprochement com o "Ocidente civilizado" a todo o custo, ele retorquiu, demonstrando um pragmatismo iniludível: "Provavelmente nisso consiste a dialética da política externa da Federação da Rússia depois da Guerra Fria. Se os campos de interesses coincidentes são ignorados - então, isto, na melhor das hipóteses, é uma repetição da Guerra Fria. Se não, já é uma parceria."13

Segundo ele, sem a política externa ativa a Rússia não realizaria transformaçôes internas de vulto, nem protegeria a sua integridade territorial. Se a Rússia quisesse se manter entre lideranças mundiais, ela deveria conduzir uma política multivetorial, "a todos os azimutes", com focos nos Estados Unidos, na Europa, na China, no Japão, na Índia, no Oriente Médio, na região da Ásia e do Pacífico, na América Latina e na África. Respondendo a si mesmo, se há potencial para isto na Rússia, ele escreve que o país é sucessor de uma potência mundial com vários atributos necessários para tal, como a influência política internacional, a importância geopolítica, o status nuclear, o assento permanente no Conselho de Segurança, o nível de desenvolvimento industrial, a cooperação internacional econômica, militar e científica. ${ }^{14}$

É notória a contribuição decisiva do governo sob a chefia de Primakov (1998-1999) para a recuperação econômica após a crise financeira de agosto de 1998. Mas, a despeito da popularidade crescente do primeiro-ministro, a postura pró-estatizante do seu governo angariou adversários poderosos entre oligarcas e, sobretudo, os aderentes da "família" do presidente Yeltsin. ${ }^{15}$ Provável candidato pelo movimento "Pátria é toda a Rússia" e um forte rival potencial de Vladimir Putin na eleiçáo presidencial de 2000, Primakov foi exonerado do cargo de primeiro-ministro em 12 de maio de 1999 por decreto de Yeltsin e, mais tarde, desistiu de participar da eleição. Ressalte-se que a política econômica dos governos posteriores, sob a direçáo de Vladimir Putin, se beneficiou indiscutivelmente da estabilização, lograda mediante o programa anticrise de Primakov.

\footnotetext{
${ }^{12}$ PRIMAKOV, E. M. Gody v bolchoi politike. Moscou: Kollêktsia “Soverchenno sekrêtno", 1999. p. 212.

${ }^{13}$ Очевидно, в этом и заключается диалектика внешней политики Российской Федерации в период после «холодной войны». Если поля совпадающих интересов игнорируются - это в лучшем случае вновь «холодная война». Если нет — это партнёрство (Ibidem, p. 212-213). (Tradução do autor.)

${ }^{14}$ Ibidem, p. 213-214.

${ }^{15}$ Grupo de pessoas, próximas ao presidente Boris Yeltsin da Rússia (1991-1999), constituído de oligarcas, administradores, membros da própria família, que exerciam uma influência política forte sobre o presidente da Rússia. Primakov usa o termo, neste contexto, justificando a exoneraçáo dele do cargo de primeiro-ministro, devido às intrigas da "família" (Cf. PRIMAKOV, E. M. Vstrêtchi na perekrióstkakh/Evguêni Primakov, op. cit., p. 525, 528, 531, 533, 546-557).
} 


\section{O "paradigma” de Primakov}

A herança intelectual deixada por Primakov é ampla e profícua, tendo dado razão à instalação na Rússia de um fórum acadêmico internacional de seus estudos. A sua obra, que se refere a várias etapas de sua carreira pública, encontra um lugar considerável na historiografia russa e estrangeira sobre a política externa. Escreve Andrey Tsygankov:

A nomeação de Primakov, novo chanceler da Rússia, marcou a finalização oficial do curso ocidentalista de Yeltsin e Kozyrev. A nova nomeação sinalizou o renascimento do mais influente paradigma da política externa da Rússia, cujo âmago foi a ideia do estadismo e do status de grande potência. ${ }^{16}$

O termo "paradigma", sugerido por Tsygankov, reflete, neste contexto, a capacidade de Primakov de reunir e expressar o discurso político de um grande grupo de estadistas russos, contrários ao curso neoliberal em economia e ciosos da preservação de interesses nacionais da nova Rússia na política internacional. $\mathrm{O}$ grupo de "derjávniki (gosudárstvenniki)", ${ }^{17}$ ao qual Primakov era atribuído, estava voltado para a reemergência da Rússia como grande potência, para a visão do sistema internacional em termos realistas, com a obrigatória centralidade da ONU e sem admitir a percepção da Rússia como Estado antiocidental. ${ }^{18}$ Denominado "nacionalismo pragmático", ${ }^{19}$ o viés de Primakov diferenciava-se do ultranacionalismo, refletindo uma transição do "paradigma pró-ocidental" a "uma posição conservadora moderada". ${ }^{20}$

Allen Lynch não identificou em Primakov a alternativa a Kozyrev, este último menos pró-ocidental na parte final da sua atuação ${ }^{21}$. Porém, Larrabee, Mankoff, Trenin e Tsygankov traçaram uma diferenciação clara entre as conceituaçóes dos dois. ${ }^{22}$ Sakwa, ao contrapor

16 Назначение Примакова, нового министа иностранных дел России, стало официальным завершением западнического курса Ельцина и Козырева. Новое назначение стало сигналом к возрождению наиболее влиятельной внешнеполитической парадигмы в России, важнейшее место в которой отводилось идее государственности и статусу великой державы (TSYGANKOV, A. P. Vniêchniaia politika Rossii ot Gorbacheva do Putina: formirovánie natsional'nogo interessa. Moscou: Nautchnaia kniga, 2008. p. 113). (Tradução do autor.)

17 “Derjávniki" (apoiadores do status de grande potência), "gosudárstvenniki” (apoiadores de um Estado forte) (nota do autor)

${ }^{18}$ TSYGANKOV, A. P. Vniêchniaia politika Rossii ot Gorbacheva do Putina: formirovánie natsional'nogo interessa, op. cit., p. 115-117.

${ }^{19}$ Apud ibidem, p. 124.

${ }^{20}$ ARBATOV, Alexei G. Russia’s Foreign Policy Alternatives. International Security, v. 18, n. 2, p. 5-43, 1993.

${ }^{21}$ LYNCH, Allen C. The Realism of Russia's Foreign Policy. Europe-Asia Studies, v. 53, n. 1, p. 7-31, 2001.

${ }^{22}$ TRENIN, Dmitri. Integratsia i identitchnost: Rossia kak "novyi Zapad". Moscou: Carnegie: 2006. p. 223229; TSYGANKOV, A. P. Vniêchniaia politika Rossii ot Gorbacheva do Putina: formirovánie natsional'nogo interessa, op. cit., p. 124. 
a "fase romântica (1992-1993)" de Kozyrev à “competitividade pragmática” de Primakov, raciocina que a formulação por Primakov do conceito do mundo multipolar significou o encolhimento da orientação política, focada predominantemente nas relações com os Estados Unidos. Outros críticos entendem que a política externa russa sob Primakov norteou-se por um corpo de ideias baseadas em um pouco de tudo: eurasianismo, realismo, idealismo e conservadorismo, ${ }^{23} \mathrm{e}$, inclusive, aproximou-se do "realismo normativo", ${ }^{24}$ reconhecendo-se, embora, que ela não podia ser interpretada meramente em termos do paradigma normativista, nem apenas com base na doutrina realista de "contenção hegemônica" do Ocidente, ${ }^{25}$ atribuída a ele. ${ }^{26}$

Meshkov vê o rumo externo multivetorial, iniciado por Primakov, ampliado e consolidado pelos governos de Vladimir Putin. ${ }^{27}$ Trenin reconhece inequivocamente a autoria de Primakov no conceito de multipolaridade. ${ }^{28}$ Pecequilo \& Luque, que associam o surgimento de Primakov na diplomacia russa com “a nova Guerra Fria”, destacaram na ação dele "a postura de autonomia”, "a recuperação da identidade russa”, “a projeção no antigo espaço soviético", "o discurso pró-multipolaridade". ${ }^{29}$

A doutrina de Primakov, de fato, representou a via de pragmatismo realista, condicionado pelo interesse nacional de sobrevivência do emergente Estado russo, diante da fragmentação do espaço pós-soviético e de face ao momento unipolar na política mundial. ${ }^{30} \mathrm{O}$ discurso político dele ficou adequado às percepçóes nacionais de como devem ser compreendidos interesses estatais e federais russos e tornou-se condizente com a etapa do ressurgimento da Rússia como grande potência. Ao mesmo tempo, a visão dele, quanto à construção do futuro das relaçóes da Rússia com o mundo e à explanação das mudanças que este mundo vem sofrendo, revela, como diz Ken Booth, um "realismo utópico", ou seja, "uma convergência da "ciência" de Marx e da "ciência" de Morgenthau": ${ }^{31}$ "A função realista da teoria política internacional é [...] prevenir suas ameaças de serem materializadas. [...] minimizar as piores

\footnotetext{
${ }^{23}$ TRENIN, Dmitri. Integratsia i identitchnost: Rossia kak "novyi Zapad”, op. cit., p. 237.

${ }^{24}$ MAIOROV, Mikhail. O nrávstvennykh i natsionalnykh interêssakh. Mezhdunarodnaia Zhizn(International affairs), n. 1-2, p. 5, 2007.

${ }_{25}$ TSYGANKOV, A. P. Vniêchniaia politika Rossii ot Gorbacheva do Putina: formirovánie natsional'nogo interessa, op. cit., p. 120, 121, 124-127.

${ }^{26}$ Ibidem, p. 152.

${ }^{27}$ MESHKOV, Alexei. Aktuaknye aspecty rossiiskoi vnechnei politiki. Mezhdunarodnaia Zhizn (International Affairs), n. 4, p. 56, 2002.

${ }^{28}$ TRENIN, Dmitri. Integratsia i identitchnost: Rossia kak "novyi Zapad”, op. cit, p. 237-238.

${ }^{29}$ PECEQUILO, Cristina Soreanu; LUQUE, Alessandra Aparecida. Estados Unidos e Rússia: convergência e divergência geopolítica (1989-2016). Meridiano 47, v. 17: e1707, p. 6, 2016.

${ }^{30}$ TSYGANKOV, A. P. Vniêchniaia politika Rossii ot Gorbacheva do Putina: formirovánie natsional'nogo interessa, op. cit., p. 117.

${ }^{31}$ BOOTH, Ken. Dare not to know: International Relations Theory versus the Future. In: BOOTH, Ken; SMITH, Steve (Eds.). International Relations Theory Today. Pensilvânia: Pennsylvania State University Press, 1995. p. 347.
} 
realidades (como a fome e a guerra) e os piores cenários (como nuclearismo e a destruição da natureza)". ${ }^{32}$

Para definir os eixos da discussão do "paradigma" primakoviano, foram selecionados aqueles aspectos da trajetória política e diplomática de Primakov e tais destaques das suas principais realizaçóes, que deram continuidade às direçôes fundamentais da política externa russa, a serem examinadas daqui em diante: o fortalecimento da segurança da Rússia perante a expansão da OTAN, a postura diante da crise no Oriente Médio e a inserção da Rússia na ordem internacional pós-Guerra Fria.

\section{O “novelo da OTAN"}

Primakov chegou a dirigir o MRE, após ter chefiado o Serviço de Inteligência Externa (SVR), ${ }^{33}$ munido das evidências de que a inteligência dos Estados Unidos começou a estabelecer redes de influência nos países da Comunidade de Estados Independentes, com o objetivo de impor o modelo de manutençáo de segurança na Europa por meio dos mecanismos da OTAN. ${ }^{34}$

Sem dúvida alguma, a garantia da segurança da Rússia depois da desintegração soviética ocupou o primeiro lugar nas prioridades da política externa, tanto no que se referia à estabilidade no "exterior próximo" quanto no tocante às ameaças externas à Rússia, como a permanência e a recomposição da OTAN depois do fim da Guerra Fria, assim como novas ameaças transnacionais e globais. Primakov batizou o relacionamento com a OTAN como o "novelo da OTAN", que deveria ser "desenredado" pela diplomacia da Rússia. ${ }^{35}$

Um dos primeiros atos, em que se vê o choque entre os conceitos de Primakov e de Kozyrev, está ligado à publicação em novembro de 1993 pelo SRV, chefiado por Primakov, do relatório "Perspectiva da expansão da OTAN e os interesses da Rússia". O conflito decorrente, descrito por Primakov, demonstrou a incompatibilidade das posiçóes sobre a OTAN na elite política russa. ${ }^{36}$

$\mathrm{Na}$ sua primeira coletiva de imprensa como chanceler, ele responde à pergunta sobre a sua polêmica com o ex-chanceler Andrey Kozyrev a respeito deste relatório do SVR, referente à ameaça da expansão da OTAN ao Leste: "Avalio negativamente a possibilidade da ex-

\footnotetext{
${ }^{32}$ The realistic function of international political theory is [...] to prevent its dangers from materializing. [...] to minimize the worst actualities (such as hunger and war) and worst possibilities (such as nuclearism and the destruction of nature) (Ibidem, p. 346-347).

${ }^{33}$ SVR, acrônimo em russo do Serviço de Inteligência Externa (Slujba Vniêshnei Razviêdki).)

${ }^{34}$ PRIMAKOV, E. M. Vstrêtchi na perekrióstkakh/Evguêni Primakov, op. cit., p. 129-130.

35 Ibidem, p. 205.

${ }^{36}$ Ibidem, p. 205-209.
} 
pansão da OTAN. Considero que isto é contraproducente para a afirmação da estabilidade na Europa e pode afetar da pior maneira a situação geopolítica da Rússia”. ${ }^{37}$

No conceito da política externa de 1997, já formulado com a sua participação direta, afirma-se que "a perspectiva da expansão da OTAN ao Leste é inadmissível", porque ela traz "ameaça de uma nova cisão do continente", em que a OTAN representaria "uma força político-militar dominante" na Europa. ${ }^{38}$

Fazendo referência aos documentos de arquivos do MRE, ele cita pronunciamentos dos líderes dos principais países da OTAN, que não alvitravam nem imaginavam a expansão do bloco: Secretário de Estado James Baker (09/02/1990): “[...] se os Estados Unidos mantiverem sua presença na Alemanha, não haverá nem uma polegada do alargamento da jurisdição ou da presença militar da OTAN em direção ao Leste"; Chanceler alemão Helmut Kohl (10/02/1990): "Consideramos que a OTAN não deve expandir a esfera de sua ação"; Primeiro-ministro britânico John Major (06/03/1991): "não prevê condições, atualmente e no futuro, sob os quais os países da Europa do Leste possam aderir à OTAN"; 39 François Mitterrand (25/05/1990): "[...] as fronteiras avançadas da OTAN [...] não devem se projetar para a parte oriental da futura Alemanha unificada." ${ }^{\circ 0}$

O chanceler soviético Eduard Shevardnadze, reportando as tratativas sobre a solução definitiva da questáo alemá ao comitê sobre assuntos exteriores do Soviete Supremo da URSS, em 20 de setembro de 1990, afirmou: "Em perspectiva, a OTAN e o Pacto de Varsóvia serão partes integrantes, elementos das estruturas pan-europeias de segurança e provavelmente se diluirão nelas."’11

A referência à postura do chanceler soviético, com relação à OTAN, refletiu a prevalência do discurso da "casa comum europeia" na política externa soviética. A convicção de Gorbachev e da equipe dos reformadores, de que a Guerra Fria e a rivalidade Leste-Oeste foram coisas do passado, provinha da suposição de que o fim da Guerra Fria tornaria inúteis

\footnotetext{
37 Я негативно отношусь к возможности расширения НАТО. Считаю, что это контрпродуктивно для устойчивой стабильности в Европе и может сказаться не лучшим образом на геополитической ситуации для России (Ibidem, p. 201). (Tradução do autor.)

${ }^{38}$ Foreign Policy and National Security of contemporary Russia, op. cit., p. 52, 60.

39 [...] если Соединённые Штаты будут сохранять в рамках НАТО своё присутствие в Германии, то не произойдёт распространения юрисдикции или военного присутствия НАТО ни на один дюйм в восточном направлении; [...] Мы считаем, что НАТО не должно расширять сферу своего действия; [...] не предвидит условий, чтобы в настоящее время и в будущем восточноевропейские страны могли бы быть в НATO. (Apud PRIMAKOV, E. M. Vstrêtchi na perekrióstkakh/Evguêni Primakov, op. cit., p. 210-211). (Tradução do autor.)

40 [...] передовые рубежи НАТО [...] не должны выдвигаться в восточную часть будущей единой Германии. (Apud Mikahil Gorbachev i guermanskiy voprós. Sb. documentov. 1986-1991. Sost., predisl. і primeytch. A. A. Galkina, A. S. Tcherniáeva/Gorbachev-Fond. Moscou: Izdatelstvo "Ves Mir", 2006. p. 451). (Tradução do autor.)

41 В перспективе НАТО и Варшавский Договор станут составными частями, элементами общеевропейских структур безопасности, а затем, видимо, и растворятся в них. (Apud ibidem, p. 577-578). (Tradução do autor.)
} 
e obsoletos os blocos político-militares. Gorbachev, ao insistir que não concordaria com a Alemanha reunificada na OTAN, batia na tecla de que novas estruturas de segurança precisavam garantir a neutralidade alemá.

Ainda antes da assinatura do Tratado sobre a solução definitiva da questão alemã (1990), a União Soviética preconizava uma neutralidade da Alemanha e uma eventual extinção de ambos os blocos militares - a OTAN e o Pacto de Varsóvia, quando negociava o projeto de uma confederação de estados europeus, denominado a "casa comum europeia", que seria vinculado ao processo de Helsinque, transformando a Conferência sobre a Segurança e Cooperação na Europa (CSCE) em seu órgão principal.

Voltando no tempo aos anos 1989-1990, cabe recordar as discussóes sobre o assunto, quando o destino da unificação alemã ainda não estava acertado. Vale lembrar o que dizia Mikhail Gorbachev, quando a questão alemã vinha sendo discutida pela liderança soviética:

O essencial é que ninguém deva calcular que a Alemanha unida iria para a OTAN. A presença de nossas tropas não o permitirá. Mas podemos retirá-las, se os americanos também retirarem as suas tropas. (p. 308) [...] Houve a Paz de Brest no 1, agora estamos na situação da "Paz de Brest" no 2 . Se não darmos conta, o que nos ameaça [...] vão decepar mais uma vez a metade do país [União Soviética]. (p. 309) 42 $^{2}$

Em entrevista ao jornal Pravda em 7 de março de 1990, Gorbachev reafirma:

Pergunta. Qual é a atitude da União Soviética a qualquer forma da associação da Alemanha unificada com a OTAN?

Resposta. Não podemos concordar com isto. É absolutamente fora de questâo. ${ }^{43}$

O chefe do departamento internacional do comitê central do partido comunista soviético, o germanista e ex-embaixador soviético na Alemanha Valentin Falin, advertiu a liderança soviética, no seu memorando de 18 de abril de 1990, sobre o desenvolvimento negativo da conjuntura de segurança europeia, se os interesses do país fossem olvidados. Ele preconizou a celebração de um tratado de paz com a Alemanha que estabelecesse a não participação da Alemanha na organizaçáo militar da OTAN (a exemplo da França). Quanto ao status militar da Alemanha, ele propôs que não houvesse a proliferação das armas de destruição em

${ }^{42}$ Главное, на что никто не должен рассчитывать, что объединённая Германия уйдёт в НАТО. Наличие наших войск этого не позволит. А убрать их мы можем, если американцы тоже уберут свои войска. (с. 308). Был Брестский мир № 1, теперь мы в ситуации «Брестского мира» № 2. Если не справимся, нам грозит... что отхватят опять полстраны. (c. 309) (Ibidem, p. 308, 309). (Tradução do autor.)

${ }^{43}$ ВОПРОС. Каково отношение Советского Союза к какой-либо форме участия объединённой Германии в НАТО? ОТВЕТ. На это мы не можем дать согласия. Это абсолютно исключено. (Ibidem, p. 381, 382). (Tradução do autor.) 
massa, sobretudo nucleares, no território da Alemanha, e que as forças armadas soviéticas fossem retiradas da Alemanha unificada junto com as tropas de outras potências vencedoras (os Estados Unidos, a Grã-Bretanha e a França). ${ }^{44}$

A causa de não pertencimento da Alemanha à OTAN, defendida pela União Soviética, esteve definitivamente perdida na etapa da unificação alemã, quando o tratado foi firmado. $\mathrm{O}$ artigo 6 do tratado estabeleceu: "O direito da Alemanha unificada de pertencer a alianças, com todos os direitos e as responsabilidades provenientes destas, não será afetado pelo presente Tratado" ${ }^{45} \mathrm{O}$ artigo 7 pôs termo a todas as obrigaçóes e aos direitos das potências vencedoras com relação à Alemanha, com a dissolução de organismos quadripartites do pós-Segunda Guerra Mundial.

Escreve Jack Matlock, o então embaixador norte-americano em Moscou e uma testemunha da desintegração soviética:

Gorbachev podia ter desempenhado o papel de atrapalhador nas negociaçóes sobre a unidade alemá e ter aprimorado o seu prestígio político em casa [...] Ele tinha 370 mil tropas na Alemanha Oriental, e nem os alemães, nem a OTAN, como um todo, poderiam ter usado força para expulsá-lo. Foi sobremaneira importante para a estabilidade do Estado unido da Alemanha que os soviéticos concordassem com o arranjo e a retirada das tropas soviéticas da Länder oriental. Foi sobremaneira importante para a Alemanha e para a OTAN que a Uniáo Soviética abrisse mão das reivindicaçóes aos direitos especiais ao solo alemão e reconhecesse o direito da Alemanha de escolher livremente suas alianças. Gorbachev podia ter engrossado a voz e ter recusado a participar dos arranjos. Se ele o fizesse, os alemães enfrentariam o dilema — ou se tornar membro da OTAN, ou se unirem, mas não as duas coisas juntas. ${ }^{46}$

Robert Service, ao examinar a reviravolta ("volte-face") da posição de Gorbachev e de Shevardnadze com relação à neutralidade da Alemanha, escreve: "A questão da reunificação alemã e a segurança econômica soviética vinham se tornando entrelaçadas [...] enquanto as

\footnotetext{
${ }^{44}$ Ibidem, p. 399.

45 The right of the united Germany to belong to alliances, with all the rights and responsibilities arising therefrom, shall not be affected by the present Treaty. (Treaty on the Final Settlement with Respect to Germany. Treaty Series n. 88 (1991). Londres: HMSO, November 1991. p. 5). (Tradução do autor.)

${ }^{46}$ Gorbachev could have played a spoiler's role in the negotiations on German unity and actually improved his political position at home. [...] He had 370,000 troops in East Germany, and neither the Germans nor NATO as a whole could have used force to expel him. It was vitally important for the stability of the united German state that the Soviets agree to the arrangement and to the withdrawal of Soviet troops from the eastern Länder. It was vitally important to Germany and NATO for the Soviet Union to relinquish all claims of special rights on German soil and to recognize the German right to choose its alliances freely. Gorbachev could have sulked and refused to participate in the arrangements. If he had, the Germans would have confronted the dilemma that they could have either NATO membership or unity - but not both (MATLOCK, Jack F. An Autopsy on an Empire. The American Ambassador's Account of the Collapse of the Soviet Union. Nova York: Random House, 1995. p. 387). (Tradução do autor.)
} 
potências ocidentais estavam ansiosas de falar sobre a nova Alemanha, elas relutavam em ajudar a economia da antiga URSS. ${ }^{\prime 47}$ Quando Helmut Kohl, chanceler da Alemanha, propôs o crédito de 5 bilhóes de marcos a Gorbachev em julho de 1990 em Arkhyz, ${ }^{48}$ o último deu aval à reunificaçáo alemá, cedendo à nova Alemanha o direito de pertencer à OTAN. O chanceler alemão prometeu que a OTAN nunca operaria no território da República Democrática Alemã, porém, nenhuma garantia formal a respeito foi dada a Gorbachev. ${ }^{49}$

A doutrina de "engajamento e alargamento" do presidente Bill Clinton definiu a política externa norte-americana nos anos 1990 com relação ao mundo pós-soviético, ${ }^{50} \mathrm{com}$ a expansão da OTAN constituindo uma peça-chave da integração de novas democracias emergentes no mundo ocidental.

Primakov, ao comentar a expansão da OTAN ao Leste, menciona o peso da memória histórica dos países pós-comunistas quanto à dominação política e militar da Europa Central e Oriental pela União Soviética, mas pondera que este não foi o elemento principal na definição da ameaça à segurança desses Estados. Primakov raciocina que, por um lado, a desistência pela OTAN da política de alargamento poderia colocar em questáo tanto a própria razão de ser do bloco militar quanto a presença militar norte-americana na Europa. Por outro, as políticas dos países do antigo bloco soviético, que ligavam o seu futuro com a próspera União Europeia, desejando se identificar com o Ocidente europeu e não com o Oriente pós-soviético, baseavam-se no raciocínio de que a adesão à OTAN abriria caminho a uma integração "mais rápida e menos onerosa" nas estruturas europeias. ${ }^{51} \mathrm{~A}$ experiência da adesão à OTAN dos países da Europa Central e Oriental provou que a condição da associaçấo com a Uniáo Europeia se implementou quase obrigatoriamente na qualidade de um país-membro da OTAN. ${ }^{2}$

Definindo a postura russa, Primakov, no encontro com o secretário britânico do exterior Malcolm Rifkind em 27 de fevereiro de 1996, frisou: "Quem quer que esteja no Kremlin, ele nunca aceitará positivamente a expansão da OTAN." ${ }^{33}$ Mas as negociaçóes com o Secretário de Estado Warren Christopher, em 21-22 de março de 1996, já evidenciaram a existên-

\footnotetext{
${ }^{47}$ The question of German reunification and Soviet economic security were becoming entwined [...] while the Western powers were eager to talk about the new Germany, they were reluctant to help the economy of the old USSR (SERVICE, Robert. The End of the Cold War. 1985-1991. London: Macmillan, 2015. p. 441, 442). (Tradução do autor.)

${ }^{48}$ Estação de esqui na Carachai-Circássia, no Norte do Cáucaso (Rússia).

${ }^{49}$ SERVICE, Robert. The End of the Cold War, op. cit., p. 447-448.

${ }^{50}$ A National Security Strategy of Engagement and Enlargement. Washington, D.C: White House, July 1994. Disponível em: http://nssarchive.us/NSSR/1994.pdf. Acesso em: 27 nov. 2016.

${ }^{51}$ PRIMAKOV, E. M. Vstrêtchi na perekrióstkakh/Evguêni Primakov, op. cit., p. 212, 213.

${ }^{52}$ CLEARY, Connor. Idealism or Betrayal? The Center on Global Interests, Washington, DC. May 24, 2017. Disponível em: http://globalinterests.org/2017/05/25/idealism-or-betrayal-what-clinton-yeltsin-rhetoricabout-nato-expansion-tells-us-about-todays-u-s-russia-crisis/. Acesso em: 15 jan. 2018.

${ }^{53}$ Кто бы ни был в Кремле, никто позитивно не воспримет расширение НАTO (PRIMAKOV, Е. М., Vstrêtchi na perekrióstkakh/Evguêni Primakov, op. cit., p. 225). (Tradução do autor.)
} 
cia de uma postura definida e rígida dos Estados Unidos com relação à expansão do bloco, muito semelhante a um ultimato: existe a ameaça aos países da Europa Central e Oriental; a liderança dos Estados Unidos na Europa é uma pré-condição para a estabilidade europeia; a Ucrânia poderia estar entre candidatos de adesão à OTAN no âmbito de sua integração europeia; não haverá interrupçôes ou pausas nas negociações com os candidatos à integração. ${ }^{54}$

Com vistas a isto a diplomacia russa identificou três principais opçôes de ação: (a) boicotar a expansão da OTAN e desistir do relacionamento com o bloco; (b) reconhecer a expansão e estabelecer a base jurídica internacional do relacionamento; (c) resistir à expansão, mas negociar com a OTAN a fim de minimizar desafios à segurança e à ameaça aos interesses do país. ${ }^{55}$ Ao se convencer de que a ideia da expansão do bloco surgiu de face à realidade da desintegração da União Soviética e por causa de abertura de vazio de poder político e militar em um espaço geopolítico da Europa Central e Oriental no pós-Guerra Fria, Primakov entendeu que a opção (c) se adequaria melhor aos interesses da Rússia nesta etapa histórica. Ou seja, seria viável procurar afastar a ameaça do enfraquecimento da Rússia, em função do fortalecimento e da expansáo da OTAN, se esses processos fossem contrabalançados por instrumentos de direito internacional, vinculados às restriçôes reais das forças convencionais na Europa, no âmbito do TLACE ${ }^{56}$ e do Tratado de Viena sobre medidas de confiança na Europa. Assim, as negociaçóes da Rússia com a OTAN incluíram na pauta um elemento obrigatório - balança de efetivos militares e de armamentos convencionais entre os dezesseis membros do bloco e a Rússia, sendo ele uma pedra de toque da construção de futuras relaçôes, com base numa "carta de segurança europeia". ${ }^{57}$

A Ata Fundamental sobre as relaçóes entre a Rússia e a OTAN, negociada por Primakov e assinada por Yeltsin em Paris em 27 de maio de 1997, apesar de criar um fórum de cooperação com a OTAN e reafirmar regimes de redução de armamentos convencionais e de reforço de medidas de confiança mútua, foi incapaz de sustar o robustecimento político-militar dos Estados Unidos na Europa ou pôr termo ao processo da expansão da OTAN ao Leste europeu.

\section{Kosovo, divisor de águas}

A desintegração soviética e o desmembramento da Iugoslávia resultaram no surgimento de 28 novos Estados na Europa e na Ásia. Na sequência dos conflitos sangrentos na ex-República da Iugoslávia, os que se destacaram em termos de sua repercussão internacional foram os da Bósnia e de Kosovo.

\footnotetext{
${ }^{54}$ Ibidem, p. 223.

${ }^{55}$ Ibidem, p. 220-221.

${ }^{56}$ TLACE - Tratado sobre a Limitação das Forças Armadas Convencionais na Europa.

${ }^{57}$ PRIMAKOV, E. M. Vstrêtchi na perekrióstkakh, op.cit., p. 236, 265-266
} 
Em Kosovo, república autônoma da Sérvia, com a maioria da população de origem albanesa, originou-se uma reinvindicação da independência. Choques entre o Exército de Libertação de Kosovo, armado do exterior e aterrorizando a população sérvia em Kosovo, por um lado, e as forças policiais da Sérvia, recorrendo às repressões contra kosovares, por outro, evoluíram para um grave conflito interétnico nesta região da Sérvia. A posição da Rússia, que se atinha à solução política do conflito, propondo restabelecer uma autonomia para Kosovo, revogada antes pela Sérvia, e evitar "catástrofe humanitária", 58 esteve em desacordo com os países da OTAN, que insistiam em medidas coercitivas, no âmbito do Capítulo VII da Carta da ONU, para coagir o presidente da Sérvia, Slobodan Milošević, a retirar-se militarmente de Kosovo.

Em 24 de março de 1999 as forças aéreas da OTAN bombardearam a Sérvia, sua capital Belgrado, à revelia das resoluçôes respectivas do Conselho de Segurança (CS) da ONU. Poucos dias antes do bombardeio, Primakov, a caminho do encontro nos Estados Unidos com o vice-presidente americano $\mathrm{Al}$ Gore, conversou por telefone com ele a bordo do avião.

Como chefe de governo, eu estava voando para os EUA para a reunião da comissão mista, sob a direção, pelo lado americano, de $\mathrm{Al}$ Gore. Eu liguei para ele de bordo do avião [...] O vicepresidente Gore, ao responder à minha pergunta direta, não me garantiu que o bombardeio não aconteceria pelo menos durante a minha visita aos Estados Unidos. Eu chamei o comandante do avião e lhe disse: estamos voltando [...] O aviāo fez a volta em cima do Atlântico e em seguida fez uma escala em Shannon. ${ }^{59}$

A firme démarche de Primakov, lembrado como a "volta sobre o Atlântico", ${ }^{60}$ com respeito ao eventual bombardeio da Iugoslávia pela OTAN, não desmentido pela alta autoridade dos Estados Unidos, foi consoante com o novo rumo da política externa russa. Ao usar força contra a Sérvia, a OTAN, uma aliança defensiva, agindo no âmbito do Capítulo VIII da Carta da ONU e assim desafiando a autoridade do CS da ONU, cometeu um ato de agressão armada contra um Estado soberano, que não atacou nenhum país da OTAN. Os bombardeios da Iugoslávia, que duraram de 24 de março a 10 de junho de 1999, resultaram na perda de cerca de mil vidas de civis e militares na Sérvia, e causaram enormes prejuízos materiais e de infraestrutura do país. Segundo Monica Hakimi:

\footnotetext{
${ }^{58}$ Ibidem, p. 316

${ }^{59}$ Как руководитель правительства, я летел в США на встречу совместной комиссии, возглавляемой с американской стороны А. Гором. Соединился с ним по телефону с борта самолёта.... Вицепрезидент Гор на прямо поставленный мною вопрос не мог дать гарантии, что удар не будет осуществлён хотя бы во время моего пребывания в США. Вызвав командира корабля, я сказал: возвращаемся. [...] Самолёт развернулся над Атлантическим океаном и промежуточно сел в Шэнноне (PRIMAKOV, E. M., Vstrêtchi na perekrióstkakh/Evguêni Primakov, op. cit., p. 319) (tradução do autor)

60 “Петля" над Атлантикой (PRIMAKOV, E. M. Vosiem mesiatsev plus... Moscou: Mysl, 2001. p. 144-152).
} 
Porém, seria bastante difícil afirmar que a ação de coerção exercida pela OTAN era consistente com o desígnio da Carta da ONU. O Artigo 53 deixa claro que acordos regionais não podem tomar medidas de coerção sem autorização do Conselho de Segurança. No caso de Kosovo, o Conselho de Segurança considerou, sim, a situação como uma ameaça à paz e à segurança internacionais, mas não autorizou nenhuma ação de coerção. ${ }^{61}$

Embora o governo de Milošević fosse tratado pela OTAN como autoritário, antidemocrático e nacionalista, conhecido pela recorrente violência contra as minorias não sérvias, o uso não autorizado da força militar no conflito de Kosovo fez com que a OTAN começasse a ser percebida não como defensora da liberdade e dos direitos humanos, mas como uma ameaça externa à soberania de Estados.

A Rússia considerou o bombardeio da Sérvia como uma mudança da estratégia global dos Estados Unidos e de seus aliados no sentido de questionar e minar a autoridade das $\mathrm{Na-}$ çôes Unidas em assuntos da manutenção da paz e da segurança internacionais e de substituir a ONU pela autoridade regional de defesa mútua, sob o fito de "intervenção humanitária”. Portanto, o uso da força militar, endossada pela OTAN contra a ex-República da Iugoslávia, deu início a um ciclo de tensôes e de manifestações de desconfiança da Rússia com relação ao bloco e provocou uma revisão gradual da parceria com a organização.

O precedente de Kosovo levou os países da Europa Centro-Oriental a vir a repensar as suas reais ou eventuais estratégias de neutralidade numa dimensão pan-europeia de segurança, conforme o espírito que se criou após a Cúpula de Paris de 1990, e a optar pela parceria ou pela aliança com a OTAN, um ator mais poderoso e mais ameaçador num contexto do desequilíbrio de poder e das transformaçóes do pós-Guerra Fria na Europa, que não poderia ser desafiado.

Após a violenta resolução do caso de Kosovo, o crescimento da OTAN desenrolou em ondas seguidas de expansão. Em 1999, a Polônia, a Hungria e a República Checa aderiram à OTAN. O estabelecimento do Conselho OTAN-Rússia, em 2002, não conteve a sua expansão para a área da antiga União Soviética - a Lituânia, a Letônia e a Estônia, chegando às fronteiras com a Rússia já em 2004. Junto com os países bálticos, mais quatro países da Europa Centro-Oriental e do Sudeste - Eslovênia, Eslováquia, Bulgária e Romênia tornaram-se membros OTAN. Essa etapa constituiu a maior ampliação do bloco desde a sua fundação. Em 2009, a Albânia e a Croácia e, em 2017, o Montenegro aderiram ao bloco militar do Norte do Atlântico. A Parceria para a Paz da OTAN tencionava

\footnotetext{
${ }^{61}$ Yet one would be hard-pressed to demonstrate that NATO's enforcement action was consistent with the design of the UN Charter. Article 53 makes clear that regional arrangements may not take enforcement actions without Security Council authorization. In the case of Kosovo, the Security Council did deem the situation to constitute a threat to international peace and security, but it did not authorize any enforcement action. (HAKIMI, Monica. To Condone or Condemn? Regional Enforcement Actions in the Absence of Security Council Authorization. Vandelbilt Journal of Transnational Law, v. 40, p. 675, 2007). (Tradução do autor.)
} 
expandir o bloco ainda mais: para a Ucrânia, a Geórgia, outros países do Cáucaso do Sul e os da Ásia Central.

Os efeitos da posterior proclamação da independência de Kosovo, em fevereiro de 2008, foram contundentes para o sistema internacional europeu e produziram uma profunda divisão entre a crescente OTAN e a Rússia. Por um lado, o surgimento de mais um Estado na Europa, bem como a desistência da OTAN de aprovar o "Plano de Ação para Adesão" para a Geórgia na reunião do Conselho da OTAN em Bucareste, em 3 de abril de 2008, ${ }^{62}$ influenciaram na decisão do presidente Saakashvili, da Geórgia, de recorrer, em agosto de 2008, à solução militar da questão da Ossétia do Sul, ${ }^{63}$ a fim de sustar a secessão daquela região, separada e de facto independente da Geórgia desde 1992. Por outro, o surgimento do Estado kosovar, separado da Sérvia, proveio o governo russo de um sólido precedente jurídico internacional para considerar a eventualidade do reconhecimento de regióes secessionistas no seu "exterior próximo".

Primakov recorda que negociaçóes, intermediadas por ele em julho de 1997, em Tbilisi, entre o líder abecásio Ardzimba e o então presidente georgiano Shevardnadze, fracassaram porque a Geórgia não admitia a autonomia da Abecásia dentro da Geórgia. ${ }^{64}$ Em outra situação parecida, ele ressalta a intransigência georgiana nas negociaçóes russo-georgianas, intermediadas por Nicolas Sarkozy em agosto de 2008, quando o presidente Saakashvili recusou-se a negociar com ossêtios, abandonou a CEI e colocou a Rússia perante a inevitável opção de estabelecer acordos sobre bases militares com os territórios independentes autodeclarados, para prevenir "novas aventuras militares" da Geórgia. ${ }^{65}$

O parecer da Corte Internacional de Justiça em Haia em que se afirmou que: "A CORTE, (3) por dez votos a quatro, é de opinião de que a declaração de independência do Kosovo, adotada em 17 de fevereiro de 2008, não violou o direito internacional”, ${ }^{66}$ foi tido pela Rússia como uma justificativa da legitimação do reconhecimento dos novos Estados no Norte do Cáucaso — a Ossétia do Sul, a Abecásia, em 2008 e, posteriormente, para a lega-

\footnotetext{
${ }^{62}$ Bucharest Summit Declaration. April, 3, 2008. Disponível em: https://www.nato.int/cps/us/natohq/official_texts_8443.htm . Acesso em: 15 nov. 2018.

${ }^{63}$ Independent International Fact-Finding Mission on the Conflict in Georgia. Report. September 2009. Vol. II, p. 107, 238. Disponível em http://www.mpil.de/en/pub/publications/archive/independent_international_fact.cfm. Acesso em: 17 nov. 2018.

${ }^{64}$ PRIMAKOV, E. M. Rossia, nadêjdy e trevógui/Evguêni Primakov. Moscou: ZAO Izdatelstvo Tsentrpoligraf, 2015. p. 194.

${ }^{65} \mathrm{Idem}$.

${ }^{66}$ THE COURT, (3) By ten votes to four, is of the opinion that the declaration of independence of Kosovo, adopted on 17 February 2008 did not violate international law. (ICJ (International Court of Justice). Accordance with international law of the unilateral declaration of independence in respect of Kosovo. Summary of 2010/2, Advisory Opinion, 22 July 2010, p. 15. Disponível em: http:/www.haguejusticeportal.net/Docs/Court\%20 Documents/ICJ/Advisory\%20Opinion\%20of\%2022\%20July\%202010.pdf. Acesso em: 4 mar. 2015). (Tradução do autor.)
} 
lidade do plebiscito sobre a autodeterminação e a independência da República Autônoma da Crimeia, e a sua unificação com a Rússia, em 2014.

\section{A Rússia e o Oriente Médio}

Primakov, arabista e estudioso do Oriente, iniciou sua carreira como jornalista no Oriente Médio. Ele chefiou o escritório do Pravda no Cairo, percorreu os países da regiáo, conhecia como poucos a conjuntura política, tinha trânsito fácil junto aos líderes árabes e curdos. Seus renome e background serviram-lhe sobremaneira quando os governos, soviético e depois russo, necessitaram de suas competências de negociador e de pacificador, primeiro, em 1990, na véspera da Guerra do Golfo, mais tarde em 1998, para evitar o bombardeio norte-americano do Iraque e, finalmente, em 2003, antes da intervençáo do Iraque pelos Estados Unidos.

Primakov escreve:

A constatação de que em 1991 podia se passar sem guerra não tem nada a ver com a benevolência com as açôes do líder iraquiano, com a postura de quem tudo e a todos perdoa, nem com a postura de resignar-se com o fato de que o Iraque detinha ou procurava deter armas de destruição em massa. ${ }^{67}$

Antes da Guerra do Golfo, por incumbência de Mikhail Gorbachev, ele visitou Bagdá por três vezes para se encontrar com Saddam Hussein. Graças às tratativas de Primakov, foram repatriados na véspera do conflito cerca de 5 mil cidadáos soviéticos e centenas de nacionais dos países ocidentais que o Iraque segurava como escudos vivos. ${ }^{68} \mathrm{Na}$ sua terceira e última visita antes da guerra, Primakov chegou muito perto de convencer Saddam Hussein a sair do Kuwait.

Primakov foi a Bagdá para conversar com líderes iraquianos de 3 a 5 de outubro de 1990. Shevardnadze havia telegrafado para ele na Jordânia no sentido de que seria imoral encontrarse com Saddam, mas Primakov defendia a opinião contrária de que era imoral ignorar as chances de um acordo pacífico. ${ }^{69}$

\footnotetext{
${ }^{67}$ Констатация того, что можно было в 1991 году обойтись без войны, не имеет ничего общего ни с одобрением действий иракского лидера, ни со всепрощенчеством, ни тем более с готовностью смириться с тем, что Ирак овладел или стремится овладеть оружием массового поражения. (PRIMAKOV, E. M. Vstrêtchi na perekrióstkakh, op. cit., p. 276). (Tradução do autor.)

${ }^{68}$ Ibidem, p. 275.

${ }^{69}$ Primakov went to Baghdad for talks with the Iraqi leadership on 3-5 October (1990). Shevardnadze had cabled him in Jordan to the effect that it would be immoral to meet Saddam — Primakov held the opposite view that it was immoral to overlook chances for a peaceful settlement. (SERVICE, Robert. The End of the Cold War, op. cit., p. 473 (itálico nosso). (Tradução do autor.)
} 
Era muito tarde para evitar o círculo vicioso da guerra, porque a decisão de castigar Bagdá já fora tomada, uma inédita coalizão anti-iraquiana formada e a liderança soviética dividida entre os "falcôes" e os "pombos" sobre a questão. Primakov foi enviado por Gorbachev a Washington para levar ao presidente George Bush condiçóes da retirada das tropas iraquianas do Kuwait, a fim de evitar o início da guerra, mas sua missão foi atropelada por Eduard Shevardnadze, que aconselhou o governo dos Estados Unidos a desconsiderar as propostas de Primakov. ${ }^{70}$

Em 1997-1998 Primakov mergulhou numa nova negociação que se desenrolara na ONU e fora dela sobre o Iraque. Mas a negociação não logrou evitar que em 16 de dezembro de 1998 os Estados Unidos — com base em relatórios da Comissão Especial das Naçôes Unidas (UNSCOM), de que houve estoques de armas de destruiçấo em massa, estes, desmentidos pela AIEA — resolvessem bombardear o Iraque e a sua capital Bagdá. Primakov, em seus contatos com o vice-presidente Gore, avisou o interlocutor: "Vocês náo podem agir a seu bel-prazer contra qualquer país. Exatamente esta abordagem leva a uma desestabilização geral."’1

Mais uma vez Primakov esteve no Iraque na véspera da intervenção dos Estados Unidos em 2003. Ele levou a Saddam Hussein uma mensagem verbal de Vladimir Putin, transmitindo o apelo ao líder iraquiano de renunciar ao cargo de presidente e convocar eleiçóes. Putin confiou a Primakov que esta talvez fosse a última chance de evitar uma intervençáo militar dos Estados Unidos no Iraque. ${ }^{72}$

Os Estados Unidos, desconsiderando os relatórios da Comissão das Naçôes Unidas de Vigilância, Verificação e Inspeção (UNMOVIC) no Iraque sobre a inexistência de provas materiais de produção e de estocagem de armamentos de extermínio em massa, sem nenhuma comprovação de atividades terroristas da $\mathrm{Al}$-Qaeda no território iraquiano e agindo à revelia da Resolução 1441 (2002) do CS da ONU, que não admitia o uso de força militar contra o Iraque, desencadearam a guerra contra o país, em 20 de março de 2003.

Primakov avaliou as consequências da intervenção militar, chamando-a de manifestação de "trotskismo", interpretando assim a ação política que apostava na "exportação" da democracia, sem levar em consideraçấo as realidades dos países-alvo desta, sendo deturpados os motivos para recurso à força. Segundo ele, a guerra resultou em caos, numa exacerbação de conflitos religiosos entre sunitas e xiitas e na deflagração de terrorismo na região. ${ }^{73}$

Situaçôes semelhantes, segundo Primakov, criaram-se na Líbia e na Síria. Na Líbia, a implementação equivocada da Resolução 1973 (2011) do CS da ONU provocou uma tragé-

${ }^{70}$ PRIMAKOV, E. M. Vstrêtchi na perekrióstkakh, op. cit., p. 277; BESCHLOSS, Michael R.;'TALBOTT, Strobe. At the Highest Levels: the Inside Story of the End of the Cold War. Nova York: Open Road, 1994. p. 232.

${ }^{71}$ Вы не можете действовать по своему усмотрению против любой страны. Именно такой подход и ведёт ко всеобщей дестабилизации (PRIMAKOV, Е. M. Vstrêtchi na perekrióstkakh, op. cit., p. 301). (Tradução do autor.)

${ }^{72}$ PRIMAKOV, E. M. Konfidentsialno: Blijni Vostok na stsêne i za kulissami (vtoraia polovina XX vêka — natchalo XXI vêka). 2-e izd., pererab. i dop. Moscou: Rossiiskaia Gazeta, 2012. p. 328.

${ }^{73}$ PRIMAKOV, E. M. Rossia, nadêjdy e trevógui, op. cit., p. 146. 
dia, que levou ao extremismo e à guerra intestina.${ }^{74} \mathrm{Na}$ Síria, a lição deveria ser aprendida, lutando contra o terrorismo internacional, buscando alianças tanto com os Estados Unidos quanto com todas as forças que se opóem ao Daesh.75

A tese principal de Primakov, quando ele escreve sobre o Oriente Médio, é que se deve evitar a substituição da ordem mundial, dividida pela linha da rivalidade ideológica entre dois sistemas político-econômicos — capitalismo vs. comunismo, por outra ordem, rachada pelas diferenças religiosas e civilizacionais, no âmbito da qual o fundamentalismo islâmico seria identificado com extremismo e terrorismo. Tal cisão seria, para ele, uma nova ameaça nascente. Para enfrentá-la, um diálogo entre civilizaçôes, comunidades socioculturais é indispensável. A crise de tal diálogo é fruto, segundo Primakov, da "obsessão irrefletida da OTAN, dirigida pelos Estados Unidos", com a "exportação", por ações armadas, do modelo ocidental da democracia para outros países, sobretudo, com a população muçulmana, ${ }^{76}$ que aconteceram em Kosovo em 1999, no Iraque em 2003, e na Líbia em 2011.

\section{A Rússia na ordem mundial}

Primakov, crítico do conceito de superpotência, entendia que a União Soviética e os Estados Unidos resolveram romper o círculo vicioso da Guerra Fria e que, neste contexto, as superpotências e os respectivos blocos antagônicos, contrapostos em virtude de uma ameaça real e recíproca de um mundo bipolar, deixaram de cumprir o seu papel. O mundo ultrapassou o estado da divisão em dois sistemas econômico-sociais, adquirindo uma outra dinâmica, mais complexa, que se refletiu na reestruturação das relaçôes internacionais, com multipolaridade, assimetrias de desenvolvimento econômico e processos de democratizaçáo crescentes sob a influência da globalização. ${ }^{77}$

Ao assumir que, após o fim da Guerra Fria, um mundo multipolar e policêntrico seria uma opção desejável tanto para a Rússia como para muitos outros países, Primakov pressupunha que a evolução da ordem mundial entraria em colisão com a política dos Estados Unidos, que visava um mundo unipolar. Porém, mesmo considerando esse contexto internacional desfavorável para a Rússia no século XXI, ele achava que a política unipolar norte-americana não significaria a negaçáo pela Rússia de numerosos campos de cooperação, para os quais os interesses dos dois países poderiam convergir, e que o desenvolvimento das relaçôes com os Estados Unidos seria uma das prioridades da política externa russa. ${ }^{78}$

\footnotetext{
${ }^{74}$ PRIMAKOV, E. M. Konfidentsialno: Blijni Vostok na stsêne i za kulíssami (vtoraia polovina XX vêka natchalo XXI vêka), op. cit., p. 388, 390-392.

${ }^{75}$ Ibidem, p. 394; PRIMAKOV, E. M. Rossia, nadêjdy e trevógui, op. cit., p. 215.

${ }^{76}$ PRIMAKOV, E. M. Konfidentsialno: Blijni Vostok na stsêne i za kulíssami (vtoraia polovina XX vêka natchalo XXI vêka), op. cit., 408.

${ }_{77}$ PRIMAKOV, Evgueni. Mnogopoliarnyi mir I OON. Mezhdunarodnaia Zhizn, n. 10, p. 97-102, 1997.

${ }_{78}$ PRIMAKOV, E. M. Vosiem mesiatsev plus..., op. cit., p. 237.
} 
Primakov enfatizava "a resistência inquestionável de numerosíssimos Estados de se concordar com a ordem mundial, moldada por uma única potência" ${ }^{79}$ A perspectiva de se posicionar fortemente, junto com o mundo em desenvolvimento, quanto ao interesse comum de resistir às intençôes hegemônicas divisórias fez dele um agente desbravador das relaçôes da nova Rússia com a América Latina, quando, nas primeiras viagens como chanceler ao exterior, ele visitou os países da região: México, Cuba e Venezuela, em maio de 1996, e a seguir, Brasil, Argentina, Colômbia e Costa Rica, em novembro de 1997.

As referidas visitas fogem da classificação de protocolares ou de retribuição. Na sua visita ao Brasil, o chanceler firmou com seu homólogo brasileiro Luiz Felipe Lampreia a declaração sobre os princípios de interação entre os dois países para o século XXI, um documento oficial de porte, criando uma plataforma de cooperação na política internacional. Dentro de um padrão atingido até então com apenas quatro Estados - Estados Unidos, França, China, Ucrânia e com a Uniāo Europeia — ${ }^{80}$ foi assinado um comunicado conjunto sobre a criação de Comissão de Alto Nível de Cooperação, lançando-se desde entáo os alicerces de uma parceria estratégica bilateral. ${ }^{81}$

Nas visitas à China e à Índia, Primakov almejava uma política russa multivetorial, mas cogitava o estabelecimento de trilateralismo russo-sino-indiano, de face à permanência do bloco remanescente da Guerra Fria - a OTAN, enquanto o seu líder, os Estados Unidos, continuava agindo, por inércia, como uma "superpotência". ${ }^{82}$ Ao lançar a ideia de um "triângulo estratégico” perante os líderes da China e da Índia em 1998, Primakov testou a viabilidade de surgimento de uma nova arquitetura multipolar da política internacional, que incluísse um grupo de governança dos países eurasiáticos, em contraposição às "tendências hegemônicas destrutivas" na política internacional, ${ }^{83}$ sem que se formasse uma aliança militar entre eles. ${ }^{84}$

Porém, apesar de naquela altura não se disporem a contemplar a ideia no plano diplomático, China e Índia vinham amadurecendo quanto à aproximação trilateral na conjuntura internacional pós-Guerra Fria. A declaração russo-chinesa sobre o mundo multipolar e a formação de uma nova ordem internacional (abril de 1996), a declaração sobre a parceria estratégica com a Índia (outubro de 2000) e o ("Grande”) Tratado de boa vizinhança, amizade e cooperaçáo com a China (julho de 2001), os dois últimos concretizados por Vladimir Putin, seguiram pari passu na esteira da iniciativa diplomática de Primakov.

\footnotetext{
79 ...бесспорное нежелание преобладающего числа государств согласиться с миропорядком, определяемым одной державой (PRIMAKOV, Е. M. Gody v bolchoi politike. Moscou: Kollêktsia "Soverchenno sekrêtno", 1999. p. 214). (Tradução do autor.)

${ }^{80}$ Foreign Policy and National Security of Contemporary Russia, op. cit.

${ }^{81}$ Cerimônia de assinatura de atos com a Rússia. MINISTÉRIO DAS RELAÇÓES EXTERIORES. Resenha de Politica Exterior do Brasil, ano 24, n. 81, p. 61-63, 2o semestre 1997.

${ }^{82}$ PRIMAKOV, E. M. Vosiem mesiatsev plus..., op. cit., p. 238.

${ }^{83}$ PRIMAKOV, E.M. Vstrêtchi na perekrióstkakh/Evguêni Primakov, op. cit., p. 183.

${ }^{84}$ LUZIANIN, S. G. Vostótchnaia política Vladimira Putina. Moscou: AST: Vostok-Zapad, 2007. p. 159-160.
} 
O RIC (Rússia-Índia-China), plataforma do diálogo trilateral, constituindo uma "identidade geopolítica", ${ }^{85}$ passou a funcionar desde 2003, por meio de um mecanismo diplomático, contribuindo para suavizar os atritos entre os vizinhos eurasiáticos. Sem ser absorvido pelo G20 ou pelo BRICS, o RIC fortaleceu a cooperaçâo multilateral desses países no âmbito da ONU e dos grupos da governança internacional.

\section{Considerações finais}

A análise textual do legado deixado por Primakov abre uma perspectiva do entendimento da condicionalidade, da racionalidade, da objetividade e da intencionalidade da doutrina da política externa seguidas pelo atual governo da Rússia.

A condicionalidade de ser sucessora da União Soviética foi um alicerce para a formulação de interesses nacionais vitais da Rússia como uma grande potência, herdeira do status legal do ordenamento do pós-Segunda Guerra Mundial e dos compromissos da União Soviética na manutenção da paz e da segurança internacionais, com base da centralidade das Naçóes Unidas na política internacional.

A objetividade da política externa da Rússia baseou-se, segundo Primakov, tanto nas noçóes do gigantismo territorial, da população multiétnica, das riquezas naturais, do potencial militar, econômico, industrial, científico e cultural quanto no fato da vizinhança fronteiriça com os estados pós-soviéticos e em função da proximidade às alianças militares hostis e aos conflitos regionais e locais.

A intencionalidade da política externa russa consistia em se proteger contra riscos de retorno a uma situação de vulnerabilidade do país em termos: (a) político-militares, semelhantes às da Guerra Fria, (b) territoriais, aquando da desintegração soviética, e (c) econômico-financeiros e sociais, semelhantes à crise da transiçăo pós-soviética.

Detentora de um dos dois maiores potenciais bélicos nucleares, a Rússia respeitou a não-proliferação nuclear e prosseguiu com a destruição paulatina das armas de destruição em massa, com base na paridade e sem obliterar a contínua modernização e reestruturação das suas forças armadas. Num artigo publicado logo depois do seu afastamento do governo, intitulado "Rússia: é duradoura a rapprochement com os Estados Unidos?" ${ }^{66}$ Primakov destacou a necessidade de chegar aos acordos com os Estados Unidos sobre três assuntos interdependentes de segurança internacional: a não militarização do espaço cósmico, um tratado sobre sistemas antimísseis e a não proliferação nuclear. ${ }^{87}$

\footnotetext{
${ }^{85}$ Ibidem, p. 160

${ }^{86}$ Россия: долговечно ли сближение с США? (PRIMAKOV, E. Rossia: dolgovechno li sblijénie s SChA? Mezhdunarodnaia Zhizn (International Affairs), n. 11, p. 113-126, 2002). (Tradução do autor.)

${ }^{87}$ Ibidem, p. 121.
} 
Primakov escreve que a Rússia não admitiria nas relaçóes com os Estados Unidos o padrão "dirigente-dirigido", reivindicando a igualdade de tratamento. "Tomarei a liberdade de dizer que nenhum líder russo se manteria no poder durante um período razoavelmente prolongado, se concordar com tal perspectiva", diz ele. "Todavia, o estímulo de manter o status de grande potência não tem nada a ver, seja com a não aceitação do papel e do lugar dos Estados Unidos no mundo atual, seja com as ambiçóes imperiais, atribuídas amiúde à Rússia contemporânea". 88

A racionalidade da política externa russa poderia ser exemplificada com os cenários "magistrais" da evolução da política internacional no início do século XXI, que Primakov contemplou. No primeiro deles, haveria a predominância nas relaçóes internacionais do "centrismo da OTAN", isto é, uma aposta no uso de força. Tal configuração faria com que a Rússia gravitasse em direção à aliança entre três países: a Rússia, a China e a Índia. Tal processo resultaria na instalação de uma nova ordem mundial, não necessariamente conducente a um choque global, mas sem garantias de não deflagração de um novo conflito mundial. ${ }^{89}$ No segundo, manter-se-iam expectativas de que as tensóes estariam se desanuviando em virtude de uma aceitação crescente pelos Estados Unidos da lógica multipolar na política internacional, do equilíbrio de interesses multilaterais, da normatividade, baseada na centralidade da ONU e no direito internacional.

No atual contexto multipolar é visível o aprofundamento da crise no relacionamento entre Rússia, China, por um lado, e Estados Unidos, por outro. Mantém-se a preocupação com: (a) a postura de excepcionalidade, dentro da lógica unipolar, que provoca receios de tentativas hegemônicas globais, (b) um endurecimento das estratégias de todos os atores mundiais, em torno do jogo de "soma zero", resultando em guerras comerciais, de informação, podendo redundar em confrontos bélicos, de consequências catastróficas à humanidade. Pari passu com a exacerbação atual do confronto militar na Europa, com os sinais da fragmentação da breve pax pós-Guerra Fria, com a crescente multipolaridade do sistema internacional, os componentes do "realismo utópico", que guiavam a diplomacia de Primakov nas relaçôes com os Estados Unidos e a OTAN, no Oriente Médio e na ação diplomática multipolar, continuam guiando a atual política externa russa.

\footnotetext{
${ }^{88}$ Возьму на себя смелость сказать, что ни один российский лидер не сможет удержаться у власти на сколько-нибудь длительный срок, согласившись на такую перспективу. Вместе с тем, стимулы сохранить статус великой державы не имеют ничего общего с непониманием места и роли США в современном мире или с имперскими амбициями, которые подчас приписывают современной России (Ibidem, p. 126). (Tradução do autor.)

${ }^{89}$ PRIMAKOV, E. Rossia i mejdunaródnyie otnochénia v uslóviiakh globalizatsii, op. cit., p. 8-9.
} 


\section{Referências}

ARBATOV, Alexei G. Russia’s Foreign Policy Alternatives. International Security, v. 18, n. 2, p. 5-43, 1993.

A NATIONAL Security Strategy of Engagement and Enlargement. Washington, D.C: White House, July 1994. Disponível em: http://nssarchive.us/NSSR/1994.pdf. Acesso em: 27 nov. 2016.

BESCHLOSS, Michael R.;'TALBOTT, Strobe. At the Highest Levels: The Inside Story of the End of the Cold War. Nova York: Open Road, 1994.

BOOTH, Ken; SMITH, Steve (Eds.). International Relations Theory Today. Pensilvânia: Pennsylvania State University Press, 1995.

BUCHAREST Summit Declaration. April, 3, 2008. Disponível em: https:/www.nato.int/ cps/us/natohq/official_texts_8443.htm. Acesso em: 15 nov. 2018.

CLEARY, Connor. Idealism or Betrayal? The Center on Global Interests, Washington, DC. May 24, 2017. Disponível em:

http://globalinterests.org/2017/05/25/idealism-or-betrayal-what-clinton-yeltsin-rhetoricabout-nato-expansion-tells-us-about-todays-u-s-russia-crisis/. Acesso em: 15 jan. 2018.

Foreign Policy and National Security of contemporary Russia. 1991-2002. Anthology in four volumes. Vol. IV. Documents. Moscou: Moscow State Institute of International Relations (University), Russian International Studies Association, ISE-Center (Information. Scholarship. Education.), 2002.

HAKIMI, Monica. To Condone or Condemn? Regional Enforcement Actions in the Absence of Security Council Authorization. Vandelbilt Journal of Transnational Law, v. 40, p. 643-685, 2007.

ICJ (International Court of Justice). Accordance with international law of the unilateral declaration of independence in respect of Kosovo. Summary of 2010/2, Advisory Opinion, 22 July 2010, p. 15. Disponível em: http://www.haguejusticeportal.net/Docs/Court\%20 Documents/ICJ/Advisory\%20Opinion\%20of\%2022\%20July\%202010.pdf. Acesso em: 4 março 2015.

ILF, Iliá Arnóldovich; PETROV, Evguêni Petróvich. Dvenadtsat’ stúliev. Zolotói teliônok. Kíev: Radziánski písmennik, 1957.

INDEPENDENT International Fact-Finding Mission on the Conflict in Georgia. Report. September 2009. Vol. II. Disponível em: http://www.mpil.de/en/pub/publications/archive/ independent_international_fact.cfm Acesso em: 17 dez. 2018.

JÉBIT, Alexandre A. Reflexôes sobre a nova concepção da política externa da Rússia. Contexto Internacional, v. 15, n. 2, p. 259-275, jul/dez. 1993. 
LARRABEE, F. Stephen; KARACIK, Theodore. Foreign and security policy decisionmaking under Yeltsin. National Defense Research Institute. Washington, D.C.: RAND, 1997.

LUZIANIN, S. G. Vostótchnaia politica Vladimira Putina. Moscou: AST: Vostok-Zapad, 2007.

LYNCH, Allen C. The Realism of Russia’s Foreign Policy. Europe-Asia Studies, v. 53, n. 1, p. 7-31, 2001.

MAIOROV, Mikhail. O nrávstvennykh i natsionalnykh interêssakh. Mezhdunarodnaia Zhizn (International Affairs), n. 1-2, p. 4-17, 2007.

MANKOFF, Jeffrey. Russia and the West: Taking the Longer View. The Washington Quarterly, v. 30, n. 2, p. 123-135, Spring 2007.

MATLOCK, Jack F. An Autopsy on an Empire. The American Ambassador's Account of the Collapse of the Soviet Union. Nova York: Random House, 1995.

MESHKOV, Alexei. Aktuaknye aspecty rossiiskoi vnechnei politiki. Mezhdunarodnaia Zhizn (International Affairs), n. 4, p. 55-61, 2002.

MIELNICZUK, Fabiano. O conflito entre Rússia e Geórgia: uma revisão histórica. Estudos Internacionais (PUC-Minas), v. 1 n. 2, p. 157-166, jul-dez 2013.

MIKHAIL GORBACHEV i guermanskiy voprós. Sb. documentov. 1986-1991. Sost., predisl. I primech. A. A. Galkina, A. S. Tcherniáeva/Gorbachev-Fond. Moscou: Izdatelstvo "Ves' Mir", 2006.

MINISTÉRIO DAS RELAÇÓES EXTERIORES. Resenha de Politica Exterior do Brasil, ano 24, n. 81, 2o semestre de 1997.

PECEQUILO, Cristina Soreanu; LUQUE, Alessandra Aparecida. Estados Unidos e Rússia: convergência e divergência geopolítica (1989-2016). Meridiano 47, v. 17:e1707, p. 1-17, 2016.

PRIMAKOV, E. M. Gody v bolchoi politike. Moscou: Kollêktsia "Soverchenno sekretno", 1999.

PRIMAKOV, E. M. Vosiem mesiatsev plus... Moscou: Mysl, 2001

PRIMAKOV, E. M. KONFIDENTSIALNO: Blijni Vostok na stsêne i za kulissami (vtoraia polovina XX vêka — natchalo XXI vêka). 2. ed., pererab. i dop. Moscou: Rossiiskaia Gazeta, 2012

PRIMAKOV, E. M. Vstrêtchi na perekrióstkakh/Evguêni Primakov. Moscou: ZAO Izdatelstvo Tsentrpoligraf, 2015

PRIMAKOV, E. M. Rossia, nadêjdy e trevógui/Evguêni Primakov. Moscou: ZAO Izdatelstvo Tsentrpoligraf, 2015

PRIMAKOV, Evgueni. Mnogopoliarnyi mir i OON. Mezhdunarodnaia Zhizn (International Affairs), n. 10, p. 97-102, 1997. 
PRIMAKOV, E. Rossia i mejdunaródnyie otnochénia v uslóviiakh globalizatsii. Mezhdunarodnaia Zhizn ((International Affairs), n. 3, p. 3-9, 2001.

PRIMAKOV, E. Rossia: dolgovechno li sblijénie s SChA? Mezhdunarodnaia Zhizn (International Affairs), n. 11, p. 113-126, 2002.

PRIMAKOV, E., akadêmik. Vnêchniaya polítika vo vsio bolchei stêpeni napravliáetsia na vosstanovlênie Rossii v kátchestve derjavy mirovogo klassa. Mezhdunarodnaia Zhizn (International Affairs), n. 1-2, p. 48-51, 2008.

PRIMAKOVSKIE TCHTÊNIA. Mejdunaródni forum. 30/11/2016. Disponível em: http:// kremlin.ru/events/president/news/53361 Acesso em: 15 nov. 2017.

REIS FILHO, Daniel Aarão. As revoluçôes russas e o socialismo soviético. São Paulo: UNESP, 2008.

SAKWA, Richard. Russian politics and society. 4 ed. Nova York: Routledge, 2008.

SEGRILLO, Ângelo. De Gorbachev a Putin: a saga da Rússia do socialismo ao capitalismo. São Paulo: Prismas, 2014.

SERVICE, Robert. The End of the Cold War. 1985-1991. Londres: Macmillan, 2015.

SIMES, Dimitri K. After the Collapse: Russia Seeks its Place as a Great Power. Nova York: Simon \& Schuster, 1999.

TREATY on the Final Settlement with Respect to Germany. Treaty Series n. 88 (1991). Londres: HMSO, November 1991.

TRENIN, Dmitri. Integratsia i identitchnost. Rossia kak "novyi Zapad". Moscou: Carnegie: 2006.

TSYGANKOV, A. P. Vniêchniaia polítika Rossii ot Gorbacheva do Putina: formirovánie natsionalnogo interessa. Moscou: Nautchnaia kniga, 2008. 